\title{
Hypoxic Stress Induces Transient Receptor Potential Melastatin 2 (TRPM2) Channel Expression in Adult Rat Cardiac Fibroblasts
}

\author{
Kenji Takahashi $^{1 *}$, Kazuho Sakamoto ${ }^{1}$, and Junko Kimura ${ }^{1}$ \\ ${ }^{1}$ Department of Pharmacology, Fukushima Medical University, School of Medicine, Fukushima 960-1295, Japan
}

Received July 15, 2011; Accepted December 6, 2011

\begin{abstract}
When cardiac tissue is exposed to hypoxia, myocytes are damaged, while fibroblasts are activated. However, it is unknown what changes are induced by hypoxia in cardiac fibroblasts. In this study, using the whole cell patch-clamp technique, we investigated the effect of hypoxia on membrane currents in fibroblasts primarily cultured from adult rat hearts. Cardiac fibroblasts were incubated for $24 \mathrm{~h}$ under normoxic or hypoxic conditions using Anaeropack. Hypoxia increased a current which reversed at around $-20 \mathrm{mV}$ in the cardiac fibroblasts. This current was inhibited by clotrimazole, which is an inhibitor of transient receptor potential melastatin 2 (TRPM2) channel and intermediate-conductance $\mathrm{Ca}^{2+}$-activated $\mathrm{K}^{+}$channel (KCa3.1). ADP ribose in the pipette solution enhanced this current. Quantitative RT-PCR revealed that mRNA of TRPM2, but not that of $\mathrm{KCa} 3.1$, was increased by hypoxia. RNA interference of TRPM2 prevented the development of the hypoxia-induced current. $\mathrm{H}_{2} \mathrm{O}_{2}$, an activator of TRPM2 channel, induced a higher $\left[\mathrm{Ca}^{2+}\right]_{i}$ elevation in hypoxia-exposed cardiac fibroblasts than that in normoxia-exposed cells. We conclude that hypoxia induces TRPM2 channel expression in adult rat cardiac fibroblasts.
\end{abstract}

Keywords: hypoxia, cardiac fibroblast, rat heart, clotrimazole, transient receptor potential melastatin 2 (TRPM2) channel

\section{Introduction}

The myocardium consists of various cell types, including cardiomyocytes, smooth muscle cells, endothelial cells, and fibroblasts. Among them, about $30 \%$ of the cells are composed of myocytes and the rest of the cells are non-myocytes (1). Fibroblasts are major non-muscle cells in the heart, which reside in the extracellular matrix (ECM), and they synthesize and secrete fibrillar collagen type I and III (2). The ECM forms a three-dimensional network that surrounds bundles of myocytes and contributes to transmission of mechanical force generated by contraction of cardiac myocytes. Cardiac fibroblasts are important not only in the healthy state, but also under pathological conditions, such as hypertension, myocardial infarction, and heart failure, which induce cardiac remodeling $(3,4)$.

In myocardial infarction, cardiac tissue is exposed to ischemia by coronary artery stenosis or embolism. If the

*Corresponding author. takahashi.kenji@toaeiyo.co.jp Published online in J-STAGE on February 1, 2012 (in advance) doi: 10.1254/jphs.11128FP area at risk remains hypoxic, the myocardium loses its contractile function, becomes necrotic, and fibrotic changes are initiated via the wound-healing process (4, 5). Cardiac fibroblasts play an important role in this process. For example, hypoxia triggers the differentiation of fibroblasts to myofibroblasts (6), leading to their matrix metalloprotease (MMP)-dependent invasion (7) with collagen synthesis (8) and resulting cardiac remodeling. Thus, hypoxia is a pathophysiological stimulus for cardiac fibroblasts. Although cardiac fibroblasts are electrically "non-excitable" cells, various membrane currents were found in rat $(9-13)$ and human cardiac fibroblasts (14), including an inward rectifier $\mathrm{K}^{+}$current, a delayed rectifier $\mathrm{K}^{+}$current, and a non-selective cation current. However, the roles of those currents are not fully understood in the function of cardiac fibroblasts.

Hypoxia is a major pathological stress for the cells in general, but the effect of hypoxia on ion channel expression is unknown in cardiac fibroblasts. In this study, we investigated the effect of hypoxia on ion channels in cardiac fibroblasts using various methods including the whole cell patch-clamp technique, pharmacological inhibition, RNA interference, and quantitative RT-PCR. 


\section{Materials and Methods}

\section{Ethical approval}

All experiments were performed with the approval of the Animal Research Committee of Fukushima Medical University.

\section{Isolation and culture of rat cardiac fibroblasts}

Adult rat cardiac fibroblasts were isolated and cultured as described previously $(13,15,16)$ with modification. In brief, male Wistar rats ( 8 - 14-week-old) were anesthetized with ether. The heart was excised and the atria and valves were removed. The ventricles were minced, and incubated in Ringer solution containing $0.3 \%$ collagenase (Wako, Tokyo) for $45 \mathrm{~min}$ at $37^{\circ} \mathrm{C}$. The Ringer solution contained $137 \mathrm{mM} \mathrm{NaCl}, 8.1 \mathrm{mM} \mathrm{NaHCO}_{3}, 2.7$ $\mathrm{mM} \mathrm{KCl}, 1.2 \mathrm{mM} \mathrm{KH}_{2} \mathrm{PO}_{4}, 1 \mathrm{mM} \mathrm{CaCl}_{2}, 0.5 \mathrm{mM} \mathrm{MgCl}_{2}$, and $10 \mathrm{mM}$ glucose ( $\mathrm{pH}$ 7.4). After centrifugation, the supernatant was extracted and suspended in Dulbecco's modified Eagle's medium (DMEM) with 10\% fetal bovine serum (FBS), $0.001 \%$ penicillin-G (Banyu Pharmaceutical, Tokyo), and streptomycin (Meiji Seika, Tokyo). Cardiac fibroblasts were separated from myocytes by selective cellular attachment. The cell suspension incubated in an uncoated plastic culture dish $(100 \mathrm{~mm})$ for 60 min at $37^{\circ} \mathrm{C}$ to allow for the preferential attachment of fibroblasts, after which unattached cells were rinsed off. Cardiac fibroblasts were maintained in a humidified atmosphere of $5 \% \mathrm{CO}_{2}$ at $37^{\circ} \mathrm{C}$ and used at passage $1-3$. Within these passages, no difference was recognized in morphology and responses of the cells to hypoxia. It was reported with this method that the purity of cultures at these passages was $>95 \%$ fibroblasts (15).

\section{Preparation of hypoxic conditions}

After a day of seeding on coverslips, cardiac fibroblasts were divided into two groups: one group was incubated under normoxic and another group, under hypoxic conditions for $24 \mathrm{~h}$ before electrophysiological analysis. Hypoxic conditions were created by using an Anaeropack (Mitsubishi Gas Chemicals, Tokyo), which contained sodium ascorbate as the principal ingredient, to absorb oxygen and generate carbon dioxide by oxidative degradation $(17,18)$. The culture dishes containing fibroblasts were placed in an airtight jar with an Anaeropack and incubated at $37^{\circ} \mathrm{C}$ for $24 \mathrm{~h}$. In the jar, the oxygen concentration was expected to decrease to a level less than $1 \%$ within $1 \mathrm{~h}$ and carbon dioxide concentration was maintained at about 5\% (18). After $24 \mathrm{~h}$, hypoxia was terminated by opening the Anaeropack jar, and the fibroblasts in the culture dishes were taken out and incubated in a $\mathrm{CO}_{2}$ incubator at $37^{\circ} \mathrm{C}$ for $30 \mathrm{~min}$. The experiments were initiated within $0.5-2 \mathrm{~h}$ after stopping the hypoxic incubation.

\section{Patch-clamp experiment}

Membrane currents were recorded from the cardiac fibroblasts by the whole-cell patch clamp method (19). The recording chamber was attached to the stage of an inverted microscope (Model 80121; Nikon, Tokyo). Cells were superfused with Tyrode solution at a rate of 1 $\mathrm{ml} / \mathrm{min}$. The temperature of the bath solution was maintained at $36^{\circ} \mathrm{C} \pm 0.5^{\circ} \mathrm{C}$ with a water jacket. Patch pipettes were forged from glass capillaries with $1.5-\mathrm{mm}$ internal diameter and 2.1-mm external diameter (Nihon Rikagaku Kikai, Tokyo) using a microelectrode puller (pp-83; Narishige, Tokyo). Pipette resistance was 2-4 M $\Omega$ when filled with the pipette solution. The pipette solution consisted of $100 \mathrm{mM} \mathrm{K}$-gluconate, $20 \mathrm{mM} \mathrm{KCl}, 16 \mathrm{mM}$ $\mathrm{KOH}, 1 \mathrm{mM} \mathrm{MgCl}$, $1 \mathrm{mM} \mathrm{CaCl}_{2}, 11 \mathrm{mM}$ EGTA, $5 \mathrm{mM}$ ATP-2Na, $16 \mathrm{mM} \mathrm{KOH}$, and $10 \mathrm{mM}$ HEPES [4-(2-hydroxyethyl)-1-piperazine-ethanesulphonic acid] ( $\mathrm{pH} 7.2$ with $\mathrm{KOH}$ ). ADP ribose was added to the pipette solution to a final concentration of $0.3 \mathrm{mM}$. Tyrode solution contained $140 \mathrm{mM} \mathrm{NaCl}, 5.4 \mathrm{mM} \mathrm{KCl}, 1.8 \mathrm{mM}$ $\mathrm{CaCl}_{2}, 1 \mathrm{mM} \mathrm{MgCl}_{2}, 0.33 \mathrm{mM} \mathrm{NaH}_{2} \mathrm{PO}_{4}, 5 \mathrm{mM}$ HEPES, and $5.5 \mathrm{mM}$ glucose (pH 7.4 with $2.4 \mathrm{mM} \mathrm{NaOH})$. The electrode was connected to a patch-clamp amplifier (CEZ-2400; Nihon Kohden, Tokyo). Recording signals were filtered at $2.5-\mathrm{kHz}$ bandwidth, and the series resistance was compensated. Current signals were stored online and analyzed using pClamp Version 9 (Axon Instruments, Union City, CA, USA). Square voltage pulses of 500-ms duration were given with a $10-\mathrm{mV}$ step increment every $10 \mathrm{~s}$ from the holding potential (HP) of $-40 \mathrm{mV}$ over the voltage range between -70 and $40 \mathrm{mV}$. The current magnitude was measured at the end of the 500-ms pulse for current-voltage relation analysis.

\section{Total RNA isolation and quantitative RT-PCR}

Total RNA was extracted from the cells using the QIAzol $^{\mathrm{TM}}$ Lysis Reagent (Qiagen, Tokyo), Qiagen RNeasy $^{\mathrm{TM}}$ Mini Kit ${ }^{\mathrm{TM}}$ (Qiagen) with the QIAcube ${ }^{\mathrm{TM}}$ (Qiagen) following the manufacturer's protocol. Reverse transcription of mRNA into cDNA was carried out using the iScript ${ }^{\mathrm{TM}}$ cDNA synthesis kit (Bio-Rad, Tokyo). Complementary DNA preparation was then stored at $-20^{\circ} \mathrm{C}$ until further use. Messenger RNA levels were quantified using a quantitative reverse transcriptase PCR (qRT-PCR) system (iCycler iQ, Bio-Rad). PCR reactions were performed with the $\mathrm{iQ}^{\mathrm{TM}} \mathrm{SYBR}^{\circledR}$ Green Supermix (Bio-Rad), using $2.5 \mu \mathrm{g}$ of cDNA as a template in each $25 \mu \mathrm{L}$ reaction mixture. The PCR protocol was as follows: an initial $10 \mathrm{~s}$ denaturation at $95^{\circ} \mathrm{C}$ followed by 40 cycles of $5 \mathrm{~s}$ of denaturation at $96^{\circ} \mathrm{C}, 10 \mathrm{~s}$ of annealing at $60^{\circ} \mathrm{C}$, and $30 \mathrm{~s}$ of extension at $72^{\circ} \mathrm{C}$. Then the PCR 
samples were cooled to $55^{\circ} \mathrm{C}, 10 \mathrm{~s}$. After that, the samples were heated to $95^{\circ} \mathrm{C}\left(0.05^{\circ} \mathrm{C} / \mathrm{s}\right)$ for the analysis of dissociation curves in the iCycler. Then the PCR samples were cooled to $40^{\circ} \mathrm{C}$. All qRT-PCR reactions were run in triplicate. The sequence of the primers and predicted lengths of the PCR products are summarized in Table 1. The primers for transient receptor potential melastatin 2 (TRPM2) were designed as described previously (20). Other sets of primer pairs were available commercially (Takara Bio, Ohtsu). As for endogenous controls, we employed ribosome 18S (r18S). The PCR products were checked by the Bioanalyzer (Agilent Technologies, Tokyo), and the specificities of the primers were confirmed by the dissociation curves and their first derivatives, each of which giving only one peak.

For quantification of cDNA, we used iCycler software version 3.0A (Bio-Rad). To generate a standard curve, the cDNA template that was mixed with all samples in each experiment was diluted four times. We adopted a six-point standard curve in each of the amplification experiments for normalization, ranging from 1/64 to 1/2 of the cDNA template. Dilutions were done with deionized water.

\section{RNA interference}

Double-stranded 25-bp small interfering (si) RNAs to the selected region of TRPM2 mRNA (Stealth Select RNAi) were purchased from Invitrogen (Tokyo). The siRNA sequences targeting rat TRPM2 are summarized in Table 2. Negative control siRNA (Medium GC Duplex, Invitrogen) was used as a control. Cardiac fibroblasts were transfected with siRNA (30 nM) using PrimaPort transfection reagent (Credia-Japan, Kyoto) according to the manufacturer's instructions. We harvested cells at $48-96 \mathrm{~h}$ after transfection.

\section{$\mathrm{Ca}^{2+}$ imaging}

To evaluate the $\mathrm{Ca}^{2+}$ response, cardiac fibroblasts were plated on glass-bottomed dishes (Matsunami, Tokyo) in DMEM with $10 \%$ FBS. After $24 \mathrm{~h}$ under the hypoxic condition, cells were loaded with $3 \mu \mathrm{M}$ Fura-2AM (Dojindo, Kumamoto) in Tyrode solution for $25 \mathrm{~min}$ at $37^{\circ} \mathrm{C}$. Measurement of Fura-2 fluorescence was performed with the Aquacosmos-Ratio imaging system (Hamamatsu Photonics, Hamamatsu). Image acquisition was maintained at a frequency of one image every $5 \mathrm{~s}$ and stored in a computer with Aquacosmos imaging software (Hamamatsu Photonics). Excitation wave lengths employed were 340 and $380 \mathrm{~nm}$, and the emis-

Table 1. Oligonucleotide primers used for PCR amplification of cDNAs

\begin{tabular}{|c|c|c|c|c|c|}
\hline Protein & Gene & Accession No. & Prim & sequences & Length (bp) \\
\hline TRPM2 & Trpm2 & AY749166 & $\begin{array}{l}\text { Fw: } \\
\text { Rv: }\end{array}$ & $\begin{array}{l}5^{\prime} \text {-GAAGGAAAGAGGGGGTGTG } \\
\text { 5' -CATTGGTGATGGCGTTGTAG }\end{array}$ & 101 \\
\hline $\mathrm{KCa} 3.1$ & Kcnn4 & NM_023021 & $\begin{array}{l}\text { Fw: } \\
\text { Rv: }\end{array}$ & $\begin{array}{l}5^{\prime} \text {-AACAAGTGAATTCCATGGTGGACA } \\
5^{\prime} \text {-TGCTGCAGGGCAGAACTGA }\end{array}$ & 160 \\
\hline TGF- $\beta 1$ & Tgfb1 & NM_021578 & $\begin{array}{l}\text { Fw: } \\
\text { Rv: }\end{array}$ & $\begin{array}{l}5 ' \text {-TGCGCCTGCAGAGATTCAAG } \\
5^{\prime} \text {-GGTAACGCCAGGAATTGTTGCTA }\end{array}$ & 82 \\
\hline p21 & Cdkn1a & NM_080782 & $\begin{array}{l}\text { Fw: } \\
\text { Rv: }\end{array}$ & $\begin{array}{l}5^{\prime} \text {-CACGGCTCAGTGGACCAGAA } \\
\text { 5' -ACTGGAGCTGCCTGAGGTAGGA }\end{array}$ & 82 \\
\hline$\alpha$-SMA & Acta2 & NM_031004 & $\begin{array}{l}\text { Fw: } \\
\text { Rv: }\end{array}$ & $\begin{array}{l}5^{\prime} \text {-AGCCAGTCGCCATCAGGAAC } \\
\text { 5' -CCGGAGCCATTGTCACACAC }\end{array}$ & 90 \\
\hline 18S rRNA & Rps18 & NM_213557 & $\begin{array}{l}\text { Fw: } \\
\text { Rv: }\end{array}$ & $\begin{array}{l}5^{\prime} \text {-AAGTTTCAGCACATCCTGCGAGTA } \\
5^{\prime} \text {-TTGGTGAGGTCAATGTCTGCTTTC }\end{array}$ & 140 \\
\hline
\end{tabular}

Table 2. Sequences of siRNA oligonucleotide used

\begin{tabular}{lllc}
\hline Name & Taget gene (accession No.) & Primers $\left(5^{\prime}-3^{\prime}\right)$ & GC contents $(\%)$ \\
\hline Trpm2-RSS309198 & TRPM2 (NM_001011559) & $\begin{array}{l}\text { UUCAGUAGACAUCUCCAAGCCACG } \\
\text { CCGUGGCUUGGAGAUGUCUACUGA }\end{array}$ & 52 \\
\cline { 2 - 4 } Trpm2-RSS309199 & TRPM2 (NM_001011559) & $\begin{array}{l}\text { AAUUCACGCCGUCAAUGUAGGUCGG } \\
\text { CCGACCUACAUUGACGGCGUGAAUU }\end{array}$ & 52 \\
\hline Trpm2-RSS309200 & TRPM2 (NM_001011559) & UAAGCGUUGAUGCUCUUCUGCCAGC & 52 \\
& & GCUGGCAGAAGAGCAUGAACGCUUA & \\
\hline
\end{tabular}


sion wavelength was $510 \mathrm{~nm}$. The fluorescence ratio (F340/F380) within an image area of an individual cell was calculated. Extracellular solutions were heated so that the temperature in a recording chamber was maintained at $37^{\circ} \mathrm{C}$.

\section{Drugs}

Clotrimazole (CLT, Wako), diisothiocyanatostilbene disulfonic acid (DIDS; Sigma, Tokyo), and 4-aminopyridine (4-AP, Sigma) were first dissolved in DMSO and added to the bath solution. The final concentration of DMSO was $0.1 \%$ or less. For control experiments, $0.1 \%$ DMSO alone was applied. Tetraethylammonium (TEA, Wako) was dissolved in water. $\mathrm{H}_{2} \mathrm{O}_{2}$ (Wako) was diluted in Tyrode solution.

\section{Analyses}

All values are presented as mean \pm S.E.M. The percent inhibition of the current magnitude was measured at 40 $\mathrm{mV}$ for various CLT concentrations. The relationship between the concentration of CLT and the rate of inhibition $(I)$ was fitted by the following equation:

$I=\left[\left(I_{\max }-I_{\min }\right) /\left(1+\left(\mathrm{IC}_{50} /[\mathrm{CLT}]\right)^{n}\right)\right]+I_{\min }$

, where $I_{\max }$ is the maximum value (which equals control conditions), $I_{\min }$ is the minimum value (which was calculated by curve fitting software: Origin version 6.1; OriginLab Corp., Northampton, MA, USA), $\mathrm{IC}_{50}$ is the median value of the concentration-inhibition curve, and $n$ is the Hill coefficient. [CLT] indicates the CLT concentration. Statistical significance between the two groups or among multiple groups was evaluated using Student's $t$-test, Tukey's test, or Dunnett's test after the F-test or one-way ANOVA.

\section{Results}

\section{Effects of hypoxia on whole-cell current in rat cardiac fibroblasts}

We first examined whether hypoxic stress affected membrane currents in cardiac fibroblasts. To do so, we recorded the whole-cell currents from cultured cardiac fibroblasts exposed to normoxia or hypoxia for $24 \mathrm{~h}$ with voltage pulses between -70 and $40 \mathrm{mV}$ from the holding potential of $-40 \mathrm{mV}$. It has been reported that cardiac fibroblasts express multiple ion channels (14). In the present study, several types of currents were observed in different fibroblasts. Figure 1, A and B, illustrates a typical set of currents from normoxia and hypoxia-exposed cells. The current which reversed at around $-20 \mathrm{mV}$ was significantly increased in both the outward and inward direction in hypoxia-exposed cells compared to those of normoxia-exposed ones. This type of current was observed with similar frequency in both groups: 8 out of 14 normoxia-exposed cells (57.1\%) and 13 out of 23 hypoxia-exposed ones (56.5\%). Other types of currents include the one that reversed at more negative potentials, possibly a $\mathrm{K}^{+}$current, and another that showed a marked timedependent decay similar to a transient outward $\mathrm{K}^{+}$current. The magnitude of these types of currents was not significantly different between normoxia and hypoxia. Thus, we selected currents that reversed at around -20 $\mathrm{mV}$ without time-dependent decay. The current amplitude was measured at the end of 500-ms square pulses at each potential and the average current density was plotted as current-voltage (I-V) relationships (Fig. 1C). The mean current density from hypoxia-exposed cells was significantly decreased at $-70 \mathrm{mV}$ and increased in the range of $10-40 \mathrm{mV}(P<0.05)$ (Fig. 1C). In hypoxiaexposed cells $(\mathrm{n}=13)$, inward current at $-70 \mathrm{mV}$ and outward current at $40 \mathrm{mV}$ were increased to $297 \%$ and $182 \%$, respectively, of those in normoxia-exposed control cells $(\mathrm{n}=8$, Fig. 1D).

The average resting potential was $-23.0 \pm 8.1 \mathrm{mV}$ $(\mathrm{n}=8)$ in the normoxic cells, and it was $-20.4 \pm 2.8 \mathrm{mV}$ $(\mathrm{n}=13)$ in hypoxia-exposed cells. Therefore, hypoxia did not change the resting potential of the fibroblasts $(P>0.05)$. The membrane capacitance was also not altered by hypoxia (data not shown). Thus, we concluded that hypoxia increased the membrane current density in rat cardiac fibroblasts.

\section{Effect of CLT on hypoxia-induced current in rat cardiac fibroblasts}

To identify the current enhanced by hypoxia, we tested several pharmacological inhibitors of $\mathrm{Cl}^{-}$channels or nonselective cation channels because the hypoxia-induced current reversed at around $-20 \mathrm{mV}$. A Cl${ }^{-}$channel inhibitor, DIDS $(100 \mu \mathrm{M})$, did not inhibit the current (data not shown), indicating that the current is not a $\mathrm{Cl}^{-}$current.

CLT is an inhibitor of a non-selective cation current through the TRPM2 channel $(21,22)$. When we tested 10 $\mu \mathrm{M}$ CLT, the current in normoxia-exposed fibroblasts were only slightly inhibited (Fig. 2: A, B, and C). However, as shown in Fig. 2D - F, CLT significantly decreased both the inward current at $-70 \mathrm{mV}$ and the outward current at $40 \mathrm{mV}$ in hypoxia-exposed cells $(\mathrm{n}=3-5, P<0.05)$. The inhibition of CLT was irreversible. Figure $2 \mathrm{G}$ illustrates the averaged I-V curves of the net CLT-sensitive current density calculated from Fig. 2, $\mathrm{C}$ and $\mathrm{F}$. The average voltage where the CLT-sensitive current reversed was at $-19.4 \pm 5.0 \mathrm{mV}(\mathrm{n}=5)$. This value coincided with the resting potential of the hypoxiainduced cells (Fig. 1). The concentration-response curve was obtained by applying various concentrations of CLT in the range from $10 \mathrm{nM}$ to $10 \mu \mathrm{M}$ (Fig. $2 \mathrm{H}$ ). The percent inhibition was calculated at $40 \mathrm{mV}$ for each CLT concen- 

A
Normoxia
B
Hypoxia
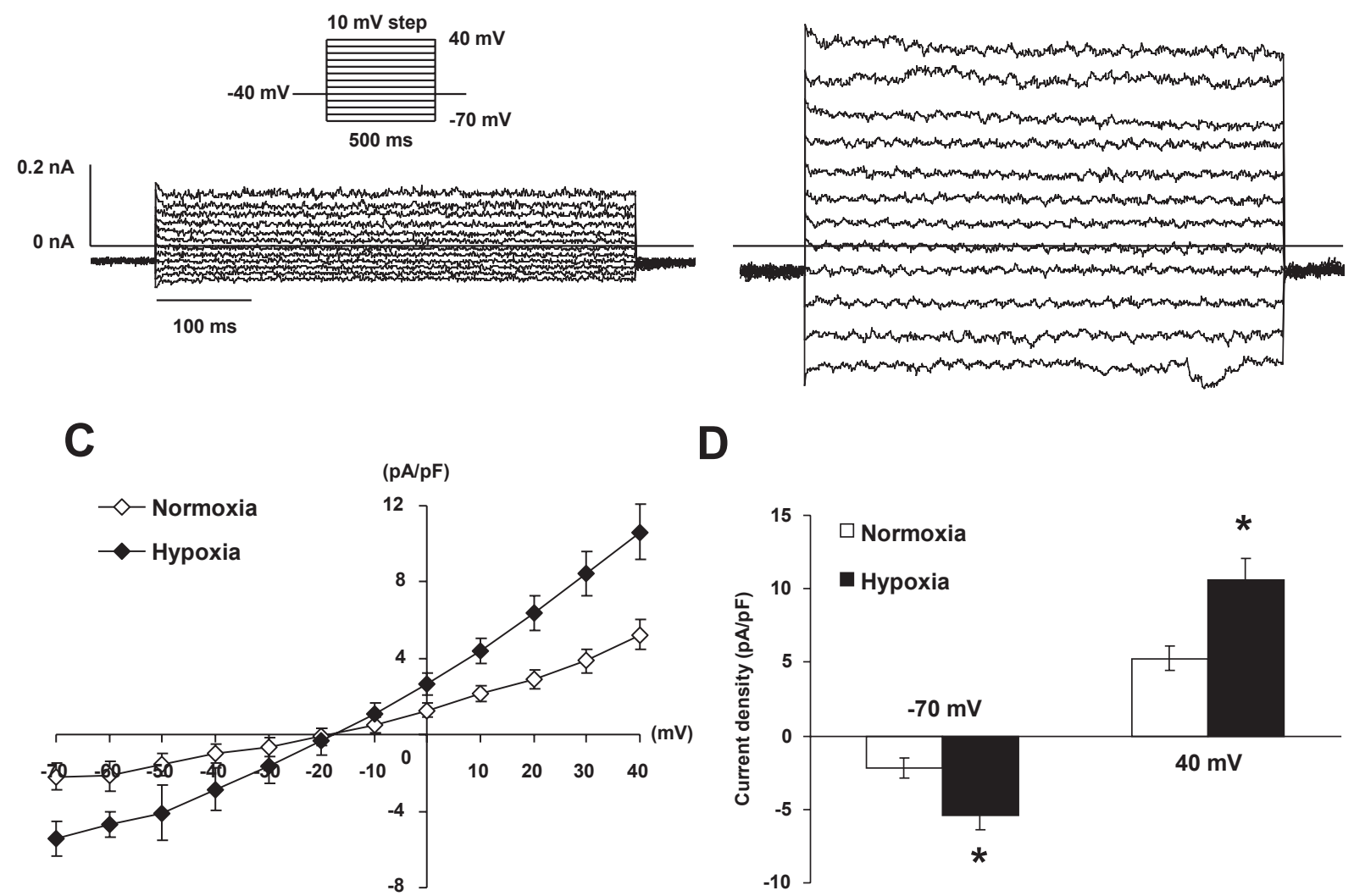

D

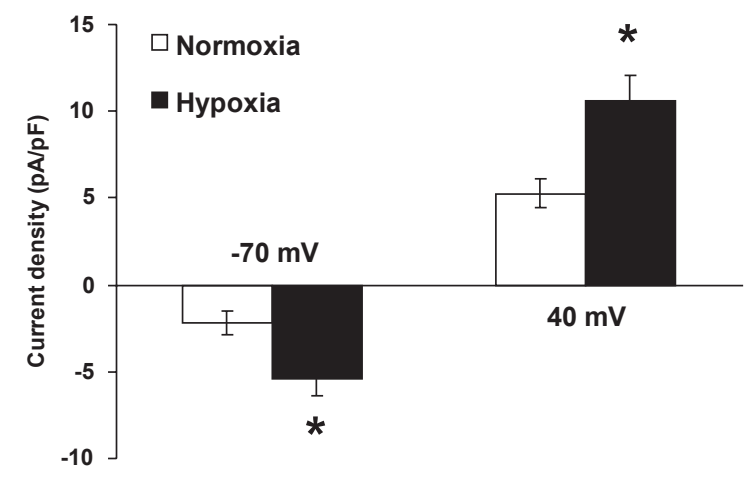

Fig. 1. Effect of hypoxia on whole-cell current in rat cardiac fibroblasts. A: Representative currents recorded from a normoxiaexposed fibroblast. The voltage pulses are illustrated in the inset. B: Representative currents recorded from a fibroblast exposed to hypoxia for $24 \mathrm{~h}$. The voltage pulses are the same as in panel A. C: Averaged isochronal I-V curves plotted from the cells exposed to normoxia (open diamonds, $\mathrm{n}=8$ ) and hypoxia (closed diamonds, $\mathrm{n}=13$ )-exposed cells. The current magnitude was measured at the end of 500-ms voltage pulses. Data are indicated as the mean \pm S.E.M. D: Current densities at -70 and $40 \mathrm{mV}$ were compared between fibroblasts exposed to normoxia and hypoxia, respectively. Each bar represents the mean \pm S.E.M. $\left({ }^{*} P<0.05\right.$, compared with normoxia; Student's $t$-test).

tration. A sigmoid curve fitting yielded a median inhibitory concentration $\left(\mathrm{IC}_{50}\right)$ of $0.7 \mu \mathrm{M}$ (Fig. $\left.2 \mathrm{H}\right)$.

We performed an additional experiment using ADP ribose and could successfully record an augmentation of the current by ADP ribose. As shown in Fig. 2I, in hypoxia-exposed cells dialyzed with the pipette solution containing ADP ribose $(0.3 \mathrm{mM})$, an inward current gradually increased and reached a peak effect by $5 \mathrm{~min}$. Similar results were observed in three other hypoxiaexposed cells. The average maximum increase of the inward current was 1.93-fold of the initial current of the measurement $(n=4)$. The increase was significant compared to those of other groups $(P<0.05$ with Tukey's test). In normoxia-exposed control cells without ADP ribose, the maximum current increase was 1.08 -fold after 5 min $(n=4)$. In normoxia-exposed cells with ADP ribose, the maximum current increase was 1.29-fold $(\mathrm{n}=4)$. In hypoxia-exposed control cells without ADP ribose, the maximum current became only 1.07 -fold after 5 min $(n=4)$. ADP ribose increased the current significantly only in hypoxia-exposed cells. Thus, we confirmed that the hypoxia-induced current is mediated via TRPM2 channels.

The $\mathrm{K}^{+}$-channel inhibitors, including 4-AP $(1 \mathrm{mM})$ and TEA $(5 \mathrm{mM})$ for voltage-dependent $\mathrm{K}^{+}$channels and glibenclamide $(10 \mu \mathrm{M})$ for ATP dependent $\mathrm{K}^{+}$channels, failed to inhibit the hypoxia-induced current (data not shown). These results indicated that the hypoxia-induced current is mediated via TRPM2 channels.

Effect of hypoxia on TRPM2 mRNA expression in rat cardiac fibroblast

Besides TRPM2 channels, CLT is also known to inhibit the intermediate conductance $\mathrm{Ca}^{2+}$-activated $\mathrm{K}^{+}$ 

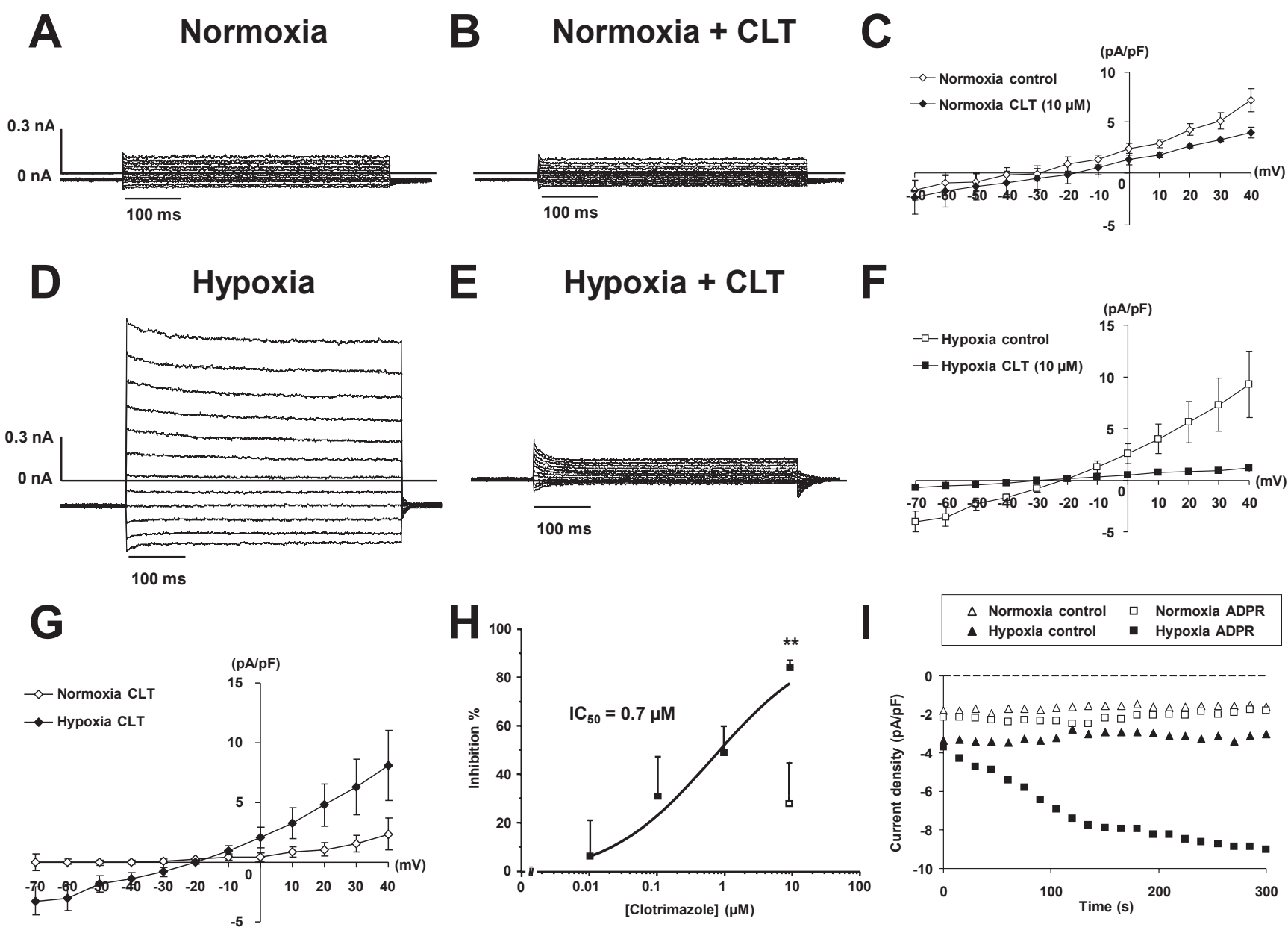

Fig. 2. Effect of clotrimazole (CLT) on the current in rat cardiac fibroblasts. A and B: Representative set of currents from a normoxia-exposed cell (A) and those in the presence of $10 \mu \mathrm{M} \mathrm{CLT} \mathrm{(B).} \mathrm{The} \mathrm{voltage} \mathrm{steps} \mathrm{are} \mathrm{the} \mathrm{same} \mathrm{in} \mathrm{Fig.} \mathrm{1A.} \mathrm{C:} \mathrm{Averaged}$ isochronal I-V curves plotted from normoxia-exposed cells in the absence (open diamonds, $\mathrm{n}=5$ ) and presence of $10 \mu \mathrm{M}$ CLT (closed diamonds, $\mathrm{n}=3$ ). The current magnitude was measured at the end of 500-ms pulses. Data are indicated as the mean \pm S.E.M. $\mathrm{D}$ and E: Representative currents recorded from fibroblasts exposed to hypoxia in the absence (D) or presence (E) of $10 \mu \mathrm{M} \mathrm{CLT}$. $\mathrm{F}$ : Averaged isochronal I-V curves plotted from hypoxia-exposed cells in the absence (open squares, $\mathrm{n}=3-5$ ) or presence of 10 $\mu \mathrm{M}$ CLT (closed squares, $\mathrm{n}=3-5$ ). The current magnitude was measured at the end of 500-ms pulses. Data are indicated as the mean \pm S.E.M. G: CLT-sensitive I-V curves obtained by the difference between a pair of I-V curves in C (normoxia; open diamonds, $\mathrm{n}=3$ ) and between those in $\mathrm{F}$ (hypoxia; closed diamonds, $\mathrm{n}=3-5$ ). Data are indicated as the mean \pm S.E.M. H: Concentration-inhibition relationships between CLT and currents at $40 \mathrm{mV}$ and different concentrations of CLT in hypoxia-exposed cells (closed squares). At $10 \mu \mathrm{M} \mathrm{CLT}$, inhibition was compared with that in normoxia (open square) $(* * P<0.01$, Student's $t$-test). The $\mathrm{IC}_{50}$ value of CLT was $0.70 \mu \mathrm{M}$. I: Effect of ADP ribose $(0.3 \mathrm{mM})$ in the pipette solution on the current recorded at $-70 \mathrm{mV}$ from fibroblasts. A voltage step pulse of 500-ms duration from a holding potential of $-40 \mathrm{mV}$ was applied every $10 \mathrm{~s}$. Representative current densities during $5 \mathrm{~min}$ are plotted. Normoxia control without ADP ribose (open triangles), normoxia with ADP ribose (open squares), hypoxia control without ADP ribose (closed triangles), and hypoxia with ADP ribose (closed squares).

channels (KCa3.1) (23). Therefore, we next examined the mRNA expression levels of TRPM2 channels and $\mathrm{KCa} 3.1$ in cardiac fibroblasts exposed to hypoxia and normoxia. In addition, we also examined the expression levels of marker mRNAs for myofibroblasts, for example, transforming growth factor (TGF)- $\beta 1$ (24), cyclin-dependent kinase inhibitor 1 (p21), and $\alpha$-smooth muscle actin ( $\alpha$-SMA) (25), because hypoxia is known to induce dif- ferentiation from fibroblasts to myofibroblasts (6). As illustrated in Fig. 3, hypoxia significantly increased mRNA levels of TRPM2 (191.8\% of the control), while TGF- $\beta 1$ and $\mathrm{p} 21 \mathrm{mRNAs}$ were decreased to $57.4 \%$ and $60.3 \%$ of the control, respectively $(\mathrm{n}=5-6)$. KCa3.1 and $\alpha$-SMA mRNA levels were not significantly different between normoxia- and hypoxia-exposed cells $(n=5-6)$. These suggested that the hypoxia-induced current was 


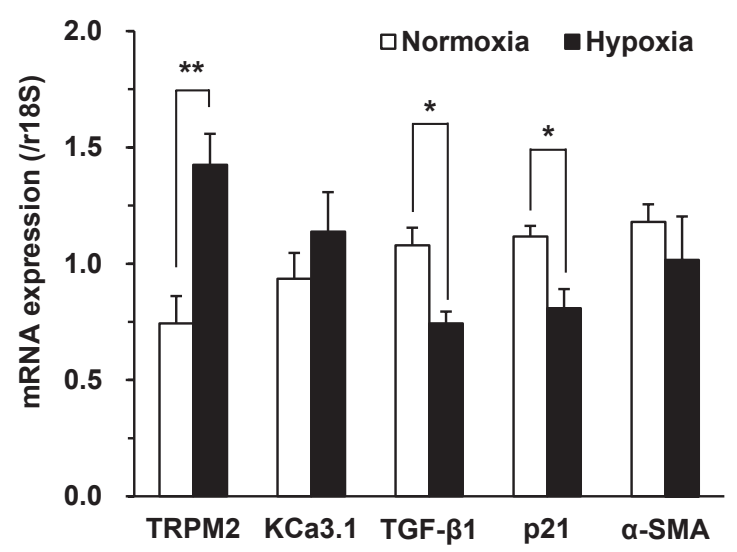

Fig. 3. Effect of hypoxia on mRNA expressions of channels and myofibroblast-marker proteins in rat cardiac fibroblasts. mRNA expression levels were quantified by qRT-PCR. Data are normalized to $18 \mathrm{~S}$ rRNA (r18S) and indicated as the mean \pm S.E.M. $(\mathrm{n}=5-6)$. $\mathrm{KCa} 3.1$, intermediate conductance $\mathrm{Ca}^{2+}$-activated $\mathrm{K}^{+}$channel; TGF- $\beta 1$, transforming growth factor-beta 1 ; p21, cyclin-dependent kinase inhibitor $1 ; \alpha$-SMA, alpha-smooth muscle actin. $(* P<0.05$, $* * P<0.01$ : compared to normoxia, Student's $t$-test).

most likely TRPM2 current, but not KCa3.1. Furthermore, hypoxia did not induce differentiation from fibroblasts to myofibroblasts in the present experiment.

\section{Effect of siRNA for TRPM2 on hypoxia-induced current}

To verify that the hypoxia-induced current was TRPM2, we used siRNA to deplete the TRPM2 expression in cardiac fibroblasts. We designed three siRNAs and tested whether they inhibit TRPM2 mRNA expression in hypoxia-exposed cells. In our hands, two siRNAs (RSS-309199 and -309200) significantly decreased the expression levels of TRPM2 mRNA at $96 \mathrm{~h}$ after transfection of siRNA ( $n=3-4$, Fig. 4A). Since RSS-309200 was most effective (Fig. 4: A and B), we used this TRPM2 siRNA for our further study. TRPM2 siRNA induced an increase of TGF- $\beta 1$ mRNA, but KCa3.1 and p21 were unaffected (Fig. 4B). When the whole-cell current was measured from the fibroblasts transfected with RSS-309200, a marked reduction in the current was seen even after 24-h hypoxia (Fig. 4: C and D). The average I-V relationships were obtained from fibroblasts with control siRNA $(n=3)$ or TRPM2 siRNA( $(n=4-5$, Fig. 4E). Both inward current at $-70 \mathrm{mV}$ and outward current at $40 \mathrm{mV}$ were significantly smaller in TRPM2 siRNAtransfected cells $(n=4-5$, Fig. $4 F)$. The average resting potentials were not significantly different between the control and TRPM2 siRNA-infected cells $(P>0.05)$. These results further support our conclusion that hypoxia induced TRPM2 channel expression in cardiac fibroblasts.
Effect of $\mathrm{H}_{2} \mathrm{O}_{2}$ on $\left[\mathrm{Ca}^{2+}\right]_{i}$ in hypoxia-exposed rat cardiac fibroblasts

The TRPM2 channel is a $\mathrm{Ca}^{2+}$-permeable nonselective cation channel. It has been reported that TRPM2-channel activity is augmented by $\mathrm{H}_{2} \mathrm{O}_{2}(26-28)$. If the hypoxiainduced current is TRPM2, $\mathrm{H}_{2} \mathrm{O}_{2}$ should elevate $\left[\mathrm{Ca}^{2+}\right]_{\mathrm{i}}$ more strongly in hypoxia-exposed cells than normoxiaexposed ones. We tested it with the Fura-2 fluorometric technique. The basal $\left[\mathrm{Ca}^{2+}\right]_{\mathrm{i}}$ in hypoxia-exposed cells tended to be higher than that in normoxia-exposed ones, although no statistical significance was obtained. $\mathrm{H}_{2} \mathrm{O}_{2}$ at $300 \mu \mathrm{M}$ increased $\left[\mathrm{Ca}^{2+}\right]_{\mathrm{i}}$ in both normoxia- and hypoxiaexposed cells. The increase in the Fura-2 ratio was higher in hypoxia- exposed fibroblasts $(\mathrm{n}=23)$ than that in normoxia-exposed ones $(n=20$, Fig. 5A). Figure 5B summarizes the area under the curve (AUC) of Fura-2 ratio in the presence of $\mathrm{H}_{2} \mathrm{O}_{2}$, which was significantly greater $(P<0.01)$ in hypoxia-exposed cells (Fig. 5B). These results further supported our conclusion that hypoxia induced TRPM2 channel expression in cardiac fibroblasts.

We could not obtain calibration of the fluorescence signals in terms of $\mathrm{Ca}^{2+}$ concentrations because many cells were detached from the bottom of the culture dish when we added $1 \mathrm{mM}$ EGTA (without $\mathrm{Ca}^{2+}$ ) or $1.8 \mathrm{mM}$ $\mathrm{Ca}^{2+}$ after permeabilization of cells with $10 \mu \mathrm{M}$ ionomycin at the end of the experiment.

\section{Discussion}

In this study, hypoxia increased a membrane current in rat cardiac fibroblasts. This current reversed at about -20 $\mathrm{mV}$, which coincided with the resting potentials of the control fibroblasts and of those exposed to hypoxia, and also with those reported previously in rat cardiac fibroblasts (12). The reversal potential of $-20 \mathrm{mV}$ suggested a possibility of $\mathrm{Cl}^{-}$channels or a nonselective cation channel. Since DIDS $(100 \mu \mathrm{M}), \mathrm{a} \mathrm{Cl}^{-}$channel inhibitor, did not inhibit the hypoxia-induced current, the possibility of $\mathrm{Cl}^{-}$channels was negated.

We found that CLT dramatically inhibited the hypoxiainduced current in cardiac fibroblasts with the $\mathrm{IC}_{50}$ of approximately $0.7 \mu \mathrm{M}$. CLT inhibits various ion channels, such as TRPM2 (21), TRPM8 (29), KCa3.1 (23), transient outward $\mathrm{K}^{+}$current, ultra-rapidly activating delayed rectifier $\mathrm{K}^{+}$current, rapidly activating delayed rectifier $\mathrm{K}^{+}$current, and slowly activating delayed rectifier $\mathrm{K}^{+}$current (30). Our CLT-sensitive hypoxia-induced current was unlikely a $\mathrm{K}^{+}$current because the reversal potential of $-20 \mathrm{mV}$ was too positive for $\mathrm{K}^{+}$channel currents, and $\mathrm{K}^{+}$channel inhibitors, such as 4-AP, TEA, and glibenclamide, failed to inhibit the hypoxia-induced current (data not shown). In addition, although CLT is 
A

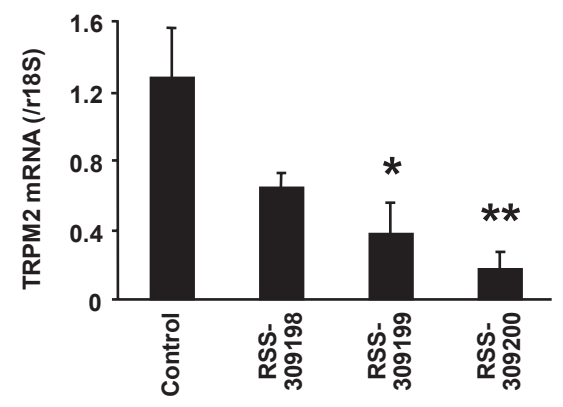

C

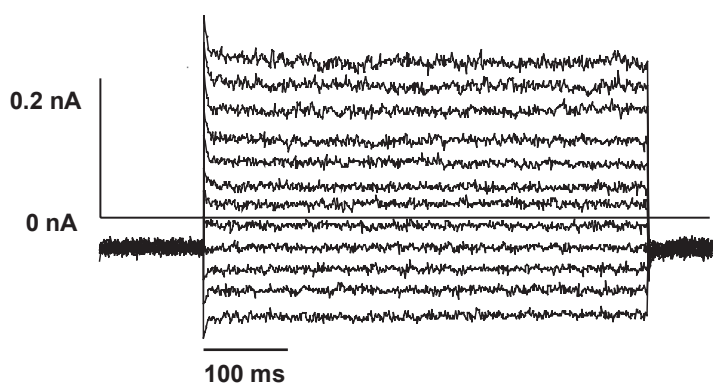

E

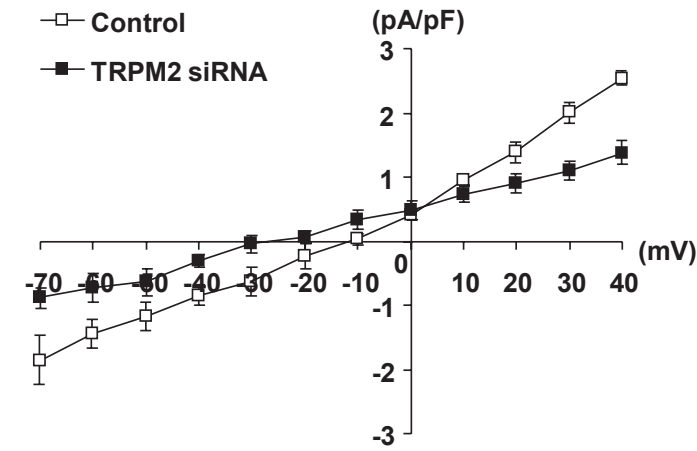

B

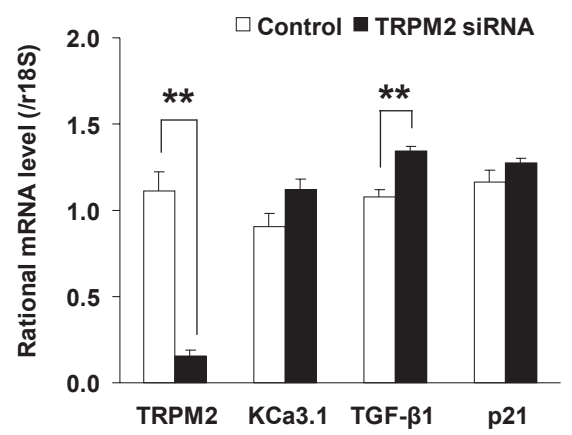

D

Hypoxia + TRPM2 siRNA

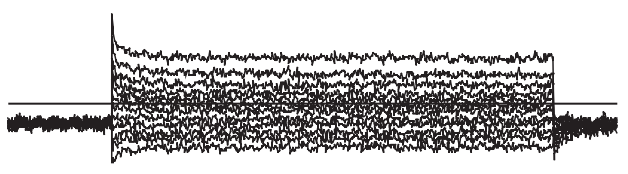

$\overline{100 \mathrm{~ms}}$

$\mathbf{F}$

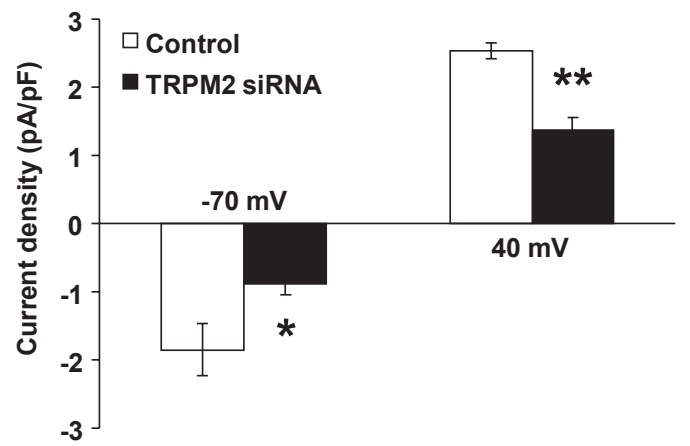

Fig. 4. Effect of siRNA for TRPM2 on hypoxia-induced current in rat cardiac fibroblasts. A: TRPM2 mRNA levels in cardiac fibroblasts at $96 \mathrm{~h}$ after transfection with three TRPM2 siRNAs (RSS-309198, -309199, and -309200). Data are normalized with 18S rRNA (r18S) and indicated as the mean \pm S.E.M. $(\mathrm{n}=3-4)(* P<0.05, * * P<0.01$ : compared to the control, Dunnett's test). B: Effects of siRNA (RSS-309200) on TRPM2 mRNA in hypoxia-exposed cells. Cells were transfected with RSS-309200 at 24-h before hypoxia and harvested after 24-h hypoxia. Data are normalized to r18S and indicated as the mean \pm S.E.M. $(n=4)$. $\left({ }^{* *} P<0.01\right.$ : compared to control, Student's $t$-test). C and D: Representative set of currents from a hypoxia-exposed cell transfected with control siRNA (C) and RSS-309200 (D). The voltage steps are the same as in Fig. 1. E: Averaged isochronal I-V curves plotted from hypoxia-exposed cells transfected with control siRNA (open squares, $\mathrm{n}=3$ ) and TRPM2 siRNA (RSS309200) (closed squares, $\mathrm{n}=4-5$ ). The current magnitude was measured at the end of 500-ms voltage pulses. Data are indicated as the mean \pm S.E.M. F: Current densities at -70 and $40 \mathrm{mV}$. Data are indicated as the mean \pm S.E.M. $(* P<0.05, * * P<0.01$ : compared to the control, Student's $t$-test).

known to inhibit $\mathrm{KCa} 3.1$ (23), the free $\mathrm{Ca}^{2+}$ concentration in our pipette solution was calculated to be about $13 \mathrm{nM}$, which was too low to activate $\mathrm{KCa} 3.1$ that requires free $\mathrm{Ca}^{2+}$ concentration higher than $200 \mathrm{nM}$ (31). Hill et al. reported in HEK293 cells expressing TRPM2 that CLT at $3-30 \mu \mathrm{M}$ completely and irreversibly inhibited the TRPM2 current, which was activated by ADP-ribose in the pipette solution (21). In the present study, we found that $10 \mu \mathrm{M}$ CLT completely and irreversibly inhibited the hypoxia-induced current. By testing CLT for $5 \mathrm{~min}$ at each concentration over the range $0.01-10 \mu \mathrm{M}$, we obtained the $\mathrm{IC}_{50}$ value of $0.7 \mu \mathrm{M}$ CLT. Hill et al. could not obtain the $\mathrm{IC}_{50}$ value of CLT because of the slow rate of block and fragility of the cells (21). They reported that the time to half block at $1 \mu \mathrm{M}$ CLT was $310 \pm 58 \mathrm{~s}$, but was $54 \pm 13 \mathrm{~s}$ at $5 \mu \mathrm{M} \mathrm{CLT}$, and that it was impossible to 
A

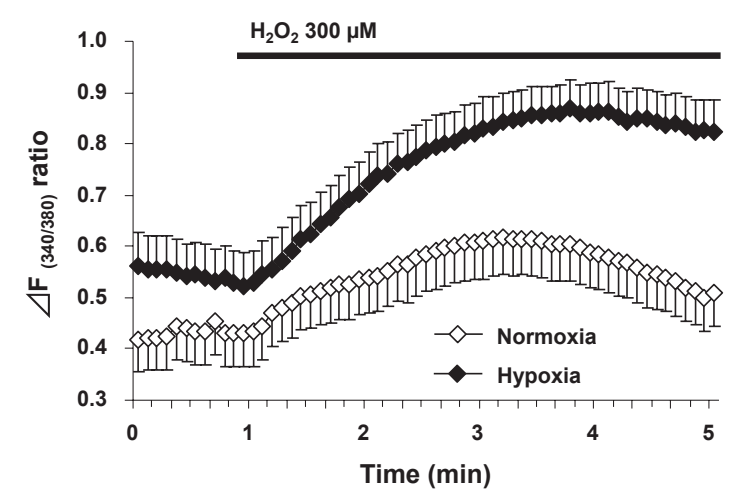

B

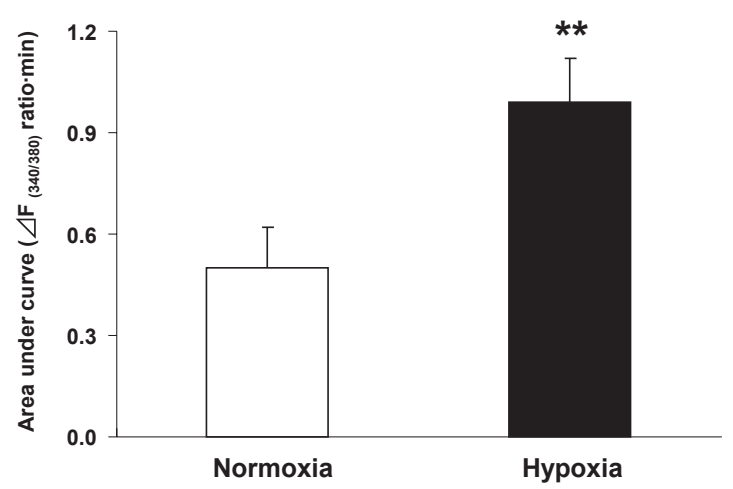

Fig. 5. Effect of $\mathrm{H}_{2} \mathrm{O}_{2}$ on $\left[\mathrm{Ca}^{2+}\right]_{\mathrm{i}}$ in cardiac fibroblasts exposed to normoxia and hypoxia. A: $\left[\mathrm{Ca}^{2+}\right]_{\mathrm{i}}$ was measured before and after addition of $300 \mu \mathrm{M} \mathrm{H}_{2} \mathrm{O}_{2}$ in the external solution. Data are indicated as the mean \pm S.E.M. of the fura- 2 ratio. Open diamonds indicate data from normoxia-exposed cells $(n=20)$ and closed diamonds indicate data from hypoxia-exposed cells $(\mathrm{n}=23)$. B: Area under curves (AUC) from panel A. Each bar indicates the mean \pm S.E.M. $(* * P<0.01$ : compared to normoxia, Student's $t$-test).

determine the level of equilibrium block at a lower concentration because prolonged activation of TRPM2 channels routinely compromises cell integrity, presumably through a combination of intracellular $\mathrm{Ca}^{2+}$ and $\mathrm{Na}^{+}$ overload (21). In our experiment without ADP-ribose in the pipette solution, the cells survived CLT application for $3-5 \mathrm{~min}$ and the $\mathrm{IC}_{50}$ value of $0.7 \mu \mathrm{M}$ CLT we obtained did not contradict the result of Hill et al. (21).

ADP-ribose is a well-known activator of TRPM2 channels (27). We added ADP ribose in the pipette solution and confirmed that the current gradually and significantly increased only in hypoxia-exposed cells, but not in normoxia-exposed cells (Fig. 2I). Therefore, we hypothesized that non-selective cation current through TRPM2 channels was increased by hypoxia in rat cardiac fibroblasts.
Supporting our hypothesis, we found that hypoxia significantly increased the mRNA levels of TRPM2 but not KCa3.1 in cardiac fibroblasts (Fig. 3). Furthermore, siRNA of TRPM2 decreased both mRNA expression levels of TRPM2 and the membrane current induced by hypoxia (Fig. 4). It has been reported that hypoxia upregulated various TRP channel expressions, such as TRPC1, TRPC4, and TRPC6, at both the mRNA and protein levels $(32,33)$. Therefore, TRPM channel expressions may also be regulated by hypoxia in a similar manner to TRPC (TRP canonical) channels.

Hypoxia is known to induce differentiation from fibroblasts to myofibroblasts (6). However, mRNA levels of myofibroblast markers, such as TGF- $\beta 1$, p21, and $\alpha$-SMA, were not increased in our hypoxia-exposed cells. This implies that within the time course of our protocol, the fibroblasts were not yet differentiated to myofibroblasts. Perhaps we harvested the cells too early for the differentiation to initiate. Thus, morphological changes of cardiac fibroblasts by hypoxia may require longer time of reoxygenation and an increase in $\left[\mathrm{Ca}^{2+}\right]_{\mathrm{i}}$. We examined whether the knockdown of TRPM2 induced changes in TGF- $\beta 1$ and $\mathrm{p} 21 \mathrm{mRNA}$ levels because increases in TGF- $\beta 1$ and $\mathrm{p} 21$ mRNA levels were reported to be signs of myofibroblast formation from fibroblasts. In the present experiment using TRPM2 siRNA, a small but significant increase of TGF- $\beta 1$ mRNA (1.25-fold of control siRNA) was observed, but p21 mRNA was unaltered (Fig. 4B). We thought, however, that this change in TGF- $\beta 1$ mRNA must not be due to myofibroblast formation because the change was so small.

In human cardiac fibroblasts, hypoxia decreased basal levels of protein and DNA synthesis in general, but it enhanced growth factor-induced DNA synthesis and basal level of collagen type I (8). Similar to collagen type I in human fibroblasts, TRPM2 mRNA was increased by hypoxia in rat cardiac fibroblasts. This mechanism of increase may be explained by the action of transcriptional factors that respond to hypoxia. In fact, it has been reported that hypoxia inducible factor 1 (HIF1), a low level under normoxia, is elevated rapidly during hypoxia and increases the expression of TRPC1 and TRPC6 in rat pulmonary arterial smooth muscle cells (33). TRPM2 channels might also be regulated by HIF-1 in cardiac fibroblasts.

The TRPM2 channel is a non-selective cation channel with little preference among various cations. $\mathrm{Ca}^{2+}$ permeability ratio against $\mathrm{Na}^{+}\left(\mathrm{P}_{\mathrm{Ca}}: \mathrm{P}_{\mathrm{Na}}\right)$ is about 0.71 in TRPM2 channels (34). Hill et al. found that replacement of external $\mathrm{Ca}^{2+}$ to $\mathrm{Ba}^{2+}$ eliminated the TRPM2 current (21). The TRPM2 channel is activated by $\mathrm{H}_{2} \mathrm{O}_{2}$, and TRPM2mediated $\mathrm{Ca}^{2+}$ influx is augmented by $\mathrm{H}_{2} \mathrm{O}_{2}(26-28)$. Indeed in our experiment, the increase in $\left[\mathrm{Ca}^{2+}\right]_{\mathrm{i}}$ induced 
by $\mathrm{H}_{2} \mathrm{O}_{2}$ in the hypoxia-exposed cells was larger than that in the normoxia-exposed ones. In our study, $\left[\mathrm{Ca}^{2+}\right]_{\mathrm{i}}$ rise induced by $\mathrm{H}_{2} \mathrm{O}_{2}$ started immediately and it took $2-3$ min to reach a maximal level. This time course is similar to that previously reported in human TRPM2 expressed in HEK cells under similar experimental conditions (28). Unexpectedly, however, CLT did not inhibit $\mathrm{H}_{2} \mathrm{O}_{2}$-induced $\left[\mathrm{Ca}^{2+}\right]_{\mathrm{i}}$ increase, but rather increased it (data not shown). It was reported that CLT inhibited $\mathrm{Ca}^{2+}$-ATPase (SERCA) 1 and SERCA2 $(35,36)$. This may explain why CLT did not inhibit $\mathrm{H}_{2} \mathrm{O}_{2}$-induced $\left[\mathrm{Ca}^{2+}\right]_{\mathrm{i}}$ increase in our hypoxia-exposed fibroblasts. We suggest that hypoxia-induced current is via TRPM2 nonselective cation channels in cardiac fibroblasts.

TRPM2 is a member of the melastatin-family of transient receptor potential channels found ubiquitously [e.g., central nervous system $(26,37)$, ventricular myocytes (38), endothelial cells (39), pancreatic $\beta$-cells (26), monocytes (40), and immune cells $(41,42)]$. However, fibroblasts expressing TRPM2 channels have been so far reported only in the symptomatic dental pulp (43). Thus, our study may be the first report of TRPM 2 in rat cardiac fibroblasts.

Because the TRPM 2 channel is enhanced by oxidative stress, its function is thought to be a sensor for oxidative stress. Hypoxia induced $\mathrm{Ca}^{2+}$ overload and death in rat neonatal cariomyocytes (44), pancreatic $\beta$-cells (45), rat brain striatal cells $(46,47)$, monocytes $(40)$, and endothelial cells (39). However, in fibroblasts, oxidative stress seems to cause an opposite response. Reactive oxygen species (ROS) activates cardiac fibroblasts to stimulate proliferation (48), collagen synthesis (8), and progression of remodeling in the heart. Thus, hypoxia-induced TRPM2 expression and $\mathrm{Ca}^{2+}$ influx may contribute to these processes in cardiac fibroblasts. However, the mechanism of fibroblast activation by increased $\mathrm{Ca}^{2+}$ influx is unclear. In fibroblasts from mouse skin, intracellular $\mathrm{Ca}^{2+}$ signaling may contribute to cell proliferation and collagen production (49). In human atrial fibroblasts, TRPM7-shRNA reduced $\mathrm{Ca}^{2+}$ influx and inhibited proliferation and differentiation induced by TGF- $\beta 1$ (50). Thus, non-selective TRP cation channels may play a key role in $\mathrm{Ca}^{2+}$ influx, which induces activation of fibroblasts and consequently fibrosis.

We conclude that hypoxia induces TRPM2 channel expression in adult rat cardiac fibroblasts. ROS enhances TRPM2 channel activation and thus increases $\mathrm{Ca}^{2+}$ entry via TRPM2 channels in cardiac fibroblasts. This may be important in the activation of fibroblasts under cardiac pathological conditions $(3,4)$. Since TRPM2 channels may make a new therapeutic target for cardiac remodeling, further investigation is necessary for the mechanism of TRPM2 expression under hypoxia in cardiac fibro- blasts.

\section{Acknowledgments}

We thank Dr. Tomoyuki Ono from Fukushima Medical University (FMU) for cell culture and Ms. Sanae Sato (FMU) for secretarial work, and we thank Mrs. Yumiko Kato and Mr. Takeshi Hasegawa from TOAEIYO Co., Ltd. for their technical assistance. We also thank Dr. Midori S. Yatabe (FMU) for reading the manuscript. This study was supported by Grants-in-Aid for Young Scientists (B) to K.S. (No. 20790210 and No.22790257) and for Scientific Research (C) to J.K. (No. 21590288) from Japan Society for the Promotion of Science, and in part from the Smoking Research Foundation (KI18003) to J.K.

\section{References}

1 Nag AC. Study of non-muscle cells of the adult mammalian heart: a fine structural analysis and distribution. Cytobios. 1980;28:41-61.

2 Eghbali M, Blumenfeld OO, Seifter S, Buttrick PM, Leinwand LA, Robinson TF, et al. Localization of types I, III and IV collagen mRNAs in rat heart cells by in situ hybridization. J Mol Cell Cardiol. 1989;21:103-113.

3 Porter KE, Turner NA. Cardiac fibroblasts: at the heart of myocardial remodeling. Pharmacol Ther. 2009;123:255-278.

4 van den Borne SW, Diez J, Blankesteijn WM, Verjans J, Hofstra L, Narula J. Myocardial remodeling after infarction: the role of myofibroblasts. Nat Rev Cardiol. 2010;7:30-37.

5 Cleutjens JP, Blankesteijn WM, Daemen MJ, Smits JF. The infarcted myocardium: simply dead tissue, or a lively target for therapeutic interventions. Cardiovasc Res. 1999;44:232-241.

6 Clancy RM, Zheng P, O'Mahony M, Izmirly P, Zavadil J, Gardner $\mathrm{L}$, et al. Role of hypoxia and cAMP in the transdifferentiation of human fetal cardiac fibroblasts: implications for progression to scarring in autoimmune-associated congenital heart block. Arthritis Rheum. 2007;56:4120-4131.

7 Morley ME, Riches K, Peers C, Porter KE. Hypoxic inhibition of human cardiac fibroblast invasion and MMP-2 activation may impair adaptive myocardial remodelling. Biochem Soc Trans. 2007;35:905-907.

8 Agocha A, Lee HW, Eghbali-Webb M. Hypoxia regulates basal and induced DNA synthesis and collagen type I production in human cardiac fibroblasts: effects of transforming growth factor- $\beta 1$, thyroid hormone, angiotensin II and basic fibroblast growth factor. J Mol Cell Cardiol. 1997;29:2233-2244.

9 Chilton L, Ohya S, Freed D, George E, Drobic V, Shibukawa Y, et al. $\mathrm{K}^{+}$currents regulate the resting membrane potential, proliferation, and contractile responses in ventricular fibroblasts and myofibroblasts. Am J Physiol Heart Circ Physiol. 2005;288: H2931-H2939.

10 Shibukawa Y, Chilton EL, Maccannell KA, Clark RB, Giles WR. $\mathrm{K}^{+}$currents activated by depolarization in cardiac fibroblasts. Biophys J. 2005;88:3924-3935.

11 Rose RA, Hatano N, Ohya S, Imaizumi Y, Giles WR. C-type natriuretic peptide activates a non-selective cation current in acutely isolated rat cardiac fibroblasts via natriuretic peptide $\mathrm{C}$ receptormediated signalling. J Physiol. 2007;580:255-274.

12 Kamkin A, Kiseleva I, Wagner KD, Lozinsky I, Gunther J, Scholz $\mathrm{H}$. Mechanically induced potentials in atrial fibroblasts from rat 
hearts are sensitive to hypoxia/reoxygenation. Pflugers Arch. 2003;446:169-174.

13 Nishida M, Onohara N, Sato Y, Suda R, Ogushi M, Tanabe S, et al. G $\alpha 12 / 13$-mediated up-regulation of TRPC6 negatively regulates endothelin-1-induced cardiac myofibroblast formation and collagen synthesis through nuclear factor of activated T cells activation. J Biol Chem. 2007;282:23117-23128.

14 Li GR, Sun HY, Chen JB, Zhou Y, Tse HF, Lau CP. Characterization of multiple ion channels in cultured human cardiac fibroblasts. PLoS One. 2009;4:e7307.

15 Gustafsson AB, Brunton LL. $\beta$-adrenergic stimulation of rat cardiac fibroblasts enhances induction of nitric-oxide synthase by interleukin- $1 \beta$ via message stabilization. Mol Pharmacol. 2000; 58:1470-1478.

16 Goldsmith EC, Hoffman A, Morales MO, Potts JD, Price RL, McFadden A, et al. Organization of fibroblasts in the heart. Dev Dyn. 2004;230:787-794.

17 Kaibori M, Inoue T, Tu W, Oda M, Kwon AH, Kamiyama Y, et al. FK506, but not cyclosporin A, prevents mitochondrial dysfunction during hypoxia in rat hepatocytes. Life Sci. 2001;69: $17-26$.

18 Kamiya T, Kwon AH, Kanemaki T, Matsui Y, Uetsuji S, Okumura T, et al. A simplified model of hypoxic injury in primary cultured rat hepatocytes. In Vitro Cell Dev Biol Anim. 1998;34:131-137.

19 Noguchi C, Yang J, Sakamoto K, Maeda R, Takahashi K, Takasugi $\mathrm{H}$, et al. Inhibitory effects of isoliquiritigenin and licorice extract on voltage-dependent $\mathrm{K}^{+}$currents in $\mathrm{H} 9 \mathrm{c} 2$ cells. J Pharmacol Sci. 2008;108:439-445.

20 Yang XR, Lin MJ, McIntosh LS, Sham JS. Functional expression of transient receptor potential melastatin- and vanilloid-related channels in pulmonary arterial and aortic smooth muscle. Am J Physiol Lung Cell Mol Physiol. 2006;290:L1267-L1276.

21 Hill K, McNulty S, Randall AD. Inhibition of TRPM2 channels by the antifungal agents clotrimazole and econazole. Naunyn Schmiedebergs Arch Pharmacol. 2004;370:227-237.

22 Olah ME, Jackson MF, Li H, Perez Y, Sun HS, Kiyonaka S, et al. $\mathrm{Ca}^{2+}$-dependent induction of TRPM2 currents in hippocampal neurons. J Physiol. 2009;587:965-979.

23 Jensen BS, Strobaek D, Christophersen P, Jorgensen TD, Hansen C, Silahtaroglu A, et al. Characterization of the cloned human intermediate-conductance $\mathrm{Ca}^{2+}$-activated $\mathrm{K}^{+}$channel. Am J Physiol. 1998;275:C848-C856.

24 Campbell SE, Katwa LC. Angiotensin II stimulated expression of transforming growth factor- $\beta 1$ in cardiac fibroblasts and myofibroblasts. J Mol Cell Cardiol. 1997;29:1947-1958.

25 Roy S, Khanna S, Rink T, Radtke J, Williams WT, Biswas S, et al. P21waf1/cip1/sdi1 as a central regulator of inducible smooth muscle actin expression and differentiation of cardiac fibroblasts to myofibroblasts. Mol Biol Cell. 2007;18:4837-4846.

26 Hara Y, Wakamori M, Ishii M, Maeno E, Nishida M, Yoshida T, et al. LTRPC2 $\mathrm{Ca}^{2+}$-permeable channel activated by changes in redox status confers susceptibility to cell death. Mol Cell. 2002; 9:163-173.

27 Wehage E, Eisfeld J, Heiner I, Jungling E, Zitt C, Luckhoff A. Activation of the cation channel long transient receptor potential channel 2 (LTRPC2) by hydrogen peroxide. A splice variant reveals a mode of activation independent of ADP-ribose. J Biol Chem. 2002;277:23150-23156.

28 Hermosura MC, Cui AM, Go RC, Davenport B, Shetler CM, Heizer JW, et al. Altered functional properties of a TRPM2 vari- ant in Guamanian ALS and PD. Proc Natl Acad Sci U S A. 2008;105:18029-18034.

29 Meseguer V, Karashima Y, Talavera K, D’Hoedt D, DonovanRodriguez T, Viana F, et al. Transient receptor potential channels in sensory neurons are targets of the antimycotic agent clotrimazole. J Neurosci. 2008;28:576-586.

30 Tian M, Dong MQ, Chiu SW, Lau CP, Li GR. Effects of the antifungal antibiotic clotrimazole on human cardiac repolarization potassium currents. Br J Pharmacol. 2006;147:289-297.

31 Wilson SM, Brown SG, McTavish N, McNeill RP, Husband EM, Inglis $\mathrm{SK}$, et al. Expression of intermediate-conductance, $\mathrm{Ca}^{2+}$ activated $\mathrm{K}^{+}$channel (KCNN4) in $\mathrm{H} 441$ human distal airway epithelial cells. Am J Physiol Lung Cell Mol Physiol. 2006;291: L957-L965.

32 Fantozzi I, Zhang S, Platoshyn O, Remillard CV, Cowling RT, Yuan JX. Hypoxia increases AP-1 binding activity by enhancing capacitative $\mathrm{Ca}^{2+}$ entry in human pulmonary artery endothelial cells. Am J Physiol Lung Cell Mol Physiol. 2003;285: L1233-L1245.

33 Wang J, Weigand L, Lu W, Sylvester JT, Semenza GL, Shimoda LA. Hypoxia inducible factor 1 mediates hypoxia-induced TRPC expression and elevated intracellular $\mathrm{Ca}^{2+}$ in pulmonary arterial smooth muscle cells. Circ Res. 2006;98:1528-1537.

34 Kraft R, Grimm C, Grosse K, Hoffmann A, Sauerbruch S, Kettenmann H, et al. Hydrogen peroxide and ADP-ribose induce TRPM2-mediated calcium influx and cation currents in microglia. Am J Physiol Cell Physiol. 2004;286:C129-C137.

35 Bartolommei G, Tadini-Buoninsegni F, Hua S, Moncelli MR, Inesi G, Guidelli R. Clotrimazole inhibits the $\mathrm{Ca}^{2+}$-ATPase (SERCA) by interfering with $\mathrm{Ca}^{2+}$ binding and favoring the E2 conformation. J Biol Chem. 2006;281:9547-9551.

36 Snajdrova L, Xu A, Narayanan N. Clotrimazole, an antimycotic drug, inhibits the sarcoplasmic reticulum calcium pump and contractile function in heart muscle. J Biol Chem. 1998;273: 28032-28039.

37 Nagamine K, Kudoh J, Minoshima S, Kawasaki K, Asakawa S, Ito $\mathrm{F}$, et al. Molecular cloning of a novel putative $\mathrm{Ca}^{2+}$ channel protein (TRPC7) highly expressed in brain. Genomics. 1998; 54:124-131.

38 Yang KT, Chang WL, Yang PC, Chien CL, Lai MS, Su MJ, et al. Activation of the transient receptor potential M2 channel and poly(ADP-ribose) polymerase is involved in oxidative stressinduced cardiomyocyte death. Cell Death Differ. 2006;13: $1815-1826$.

39 Yao X, Garland CJ. Recent developments in vascular endothelial cell transient receptor potential channels. Circ Res. 2005;97: 853-863.

40 Yamamoto S, Shimizu S, Kiyonaka S, Takahashi N, Wajima T, Hara Y, et al. TRPM2-mediated $\mathrm{Ca}^{2+}$ influx induces chemokine production in monocytes that aggravates inflammatory neutrophil infiltration. Nat Med. 2008;14:738-747.

41 Gasser A, Glassmeier G, Fliegert R, Langhorst MF, Meinke S, Hein $\mathrm{D}$, et al. Activation of $\mathrm{T}$ cell calcium influx by the second messenger ADP-ribose. J Biol Chem. 2006;281:2489-2496.

42 Sano $\mathrm{Y}$, Inamura $\mathrm{K}$, Miyake A, Mochizuki S, Yokoi H, Matsushime $\mathrm{H}$, et al. Immunocyte $\mathrm{Ca}^{2+}$ influx system mediated by LTRPC2. Science. 2001;293:1327-1330.

43 Rowland KC, Kanive CB, Wells JE, Hatton JF. TRPM2 immunoreactivity is increased in fibroblasts, but not nerves, of symptomatic human dental pulp. J Endod. 2007;33:245-248. 
44 Long X, Boluyt MO, Hipolito ML, Lundberg MS, Zheng JS, O'Neill L, et al. p53 and the hypoxia-induced apoptosis of cultured neonatal rat cardiac myocytes. J Clin Invest. 1997;99: 2635-2643.

45 Rosen P, Nawroth PP, King G, Moller W, Tritschler HJ, Packer L. The role of oxidative stress in the onset and progression of diabetes and its complications: a summary of a Congress Series sponsored by UNESCO-MCBN, the American Diabetes Association and the German Diabetes Society. Diabetes Metab Res Rev. 2001;17:189-212.

46 Fonfria E, Marshall IC, Boyfield I, Skaper SD, Hughes JP, Owen $\mathrm{DE}$, et al. Amyloid $\beta$-peptide(1-42) and hydrogen peroxide-induced toxicity are mediated by TRPM2 in rat primary striatal cultures. J Neurochem. 2005;95:715-723.

47 Smith MA, Herson PS, Lee K, Pinnock RD, Ashford ML. Hydro- gen-peroxide-induced toxicity of rat striatal neurones involves activation of a non-selective cation channel. J Physiol. 2003; 547:417-425.

48 Li PF, Dietz R, von Harsdorf R. Superoxide induces apoptosis in cardiomyocytes, but proliferation and expression of transforming growth factor- $\beta 1$ in cardiac fibroblasts. FEBS Lett. 1999;448: 206-210.

49 Youm JK, Jo H, Hong JH, Shin DM, Kwon MJ, Jeong SK, et al. $\mathrm{K} 6 \mathrm{PC}-5$, a sphingosine kinase activator, induces anti-aging effects in intrinsically aged skin through intracellular Ca2+ signaling. J Dermatol Sci. 2008;51:89-102.

50 Du J, Xie J, Zhang Z, Tsujikawa H, Fusco D, Silverman D, et al. TRPM7-mediated $\mathrm{Ca}^{2+}$ signals confer fibrogenesis in human atrial fibrillation. Circ Res. 2010;106:992-1003. 